\title{
Antixenosis of bean genotypes to Chrysodeixis includens (Lepidoptera: Noctuidae)
}

\author{
Rafaela Morando(1), Edson Luiz Lopes Baldin(1), Patrícia Leite Cruz ${ }^{(1)}$, \\ André Luiz Lourenção(2) and Alisson Fernando Chiorato(2)
}

\begin{abstract}
(1) Universidade Estadual Paulista, Faculdade de Ciências Agronômicas, Campus de Botucatu, Rua José Barbosa de Barros, no 1.780, Caixa Postal 237, CEP 18610-307 Botucatu, SP, Brazil. E-mail: rafaela_morando@hotmail.com, elbaldin@fca.unesp.br, patricia.agronomia@gmail.com ${ }^{(2) I n s t i t u t o A g r o n o ̂ m i c o, A v e n i d a B a r a ̃ o ~ d e ~ I t a p u r a, ~ № 1.481, ~ C a i x a ~ P o s t a l 28, ~ C E P 13012-970 ~ C a m p i n a s, ~ S P, ~ B r a z i l . ~}$ E-mail: andre@iac.sp.gov.br, afchiorato@iac.sp.gov.br
\end{abstract}

\begin{abstract}
The objective of this work was to evaluate bean genotypes for resistance to soybean looper (Chrysodeixis includens). Initially, free-choice tests were carried out with 59 genotypes, divided into three groups according to leaf color intensity (dark green, light green, and medium green), in order to evaluate oviposition preference. Subsequently, 12 genotypes with high potential for resistance were selected, as well as two susceptible commercial standards. With these genotypes, new tests were performed for oviposition in a greenhouse, besides tests for attractiveness and consumption under laboratory conditions $\left(26 \pm 2^{\circ} \mathrm{C}, 65 \pm 10 \%\right.$ $\mathrm{RH}$, and $14 \mathrm{~h}$ light: $10 \mathrm{~h}$ dark photophase). In the no-choice test with adults, in the greenhouse, the 'IAC Jabola', Arcelina 1, 'IAC Boreal', 'Flor de Mayo', and 'IAC Formoso' genotypes were the least oviposited, showing antixenosis-type resistance for oviposition. In the free-choice test with larvae, Arcelina 4, 'BRS Horizonte', 'Pérola', H96A102-1-1-1-52, 'IAC Boreal', 'IAC Harmonia', and 'IAC Formoso' were the less consumed genotypes, which indicates antixenosis to feeding. In the no-choice test, all genotypes (except for 'IAPAR 57') expressed moderate levels of antixenosis to feeding against $C$. includens larvae.
\end{abstract}

Index terms: common bean, host plant resistance, nonpreference, resistance mechanisms, soybean looper.

\section{Antixenose de genótipos de feijoeiro a Chrysodeixis includens (Lepidoptera: Noctuidae)}

Resumo - O objetivo deste trabalho foi avaliar genótipos de feijoeiro quanto à resistência a lagarta-falsamedideira (Chrysodeixis includens). Inicialmente, foram realizados testes com chance de escolha com 59 genótipos, divididos em três grupos, de acordo com a intensidade de coloração das folhas (verde-escura, verde-clara e verde-médio), para avaliar a preferência quanto à oviposição. Em seguida, selecionaram-se 12 genótipos com grande potencial de resistência, assim como dois padrões comerciais suscetíveis. Com estes genótipos, realizaram-se novos ensaios de oviposição, em casa de vegetação, além de testes de atratividade e consumo, em condições de laboratório $\left(26 \pm 2^{\circ} \mathrm{C}, 65 \pm 10 \%\right.$ UR e fotófase de $14 \mathrm{~h}$ luz: $10 \mathrm{~h}$ escuro). No teste sem chance de escolha, com adultos, em casa de vegetação, os genótipos 'IAC Jabola', Arcelina 1, 'IAC Boreal', 'Flor de Mayo' e 'IAC Formoso' foram os menos ovipositados, tendo apresentado resistência do tipo antixenose à oviposição. No teste com chance de escolha, com larvas, Arcelina 4, 'BRS Horizonte', 'Pérola', H96A102-1-1-1-52, 'IAC Boreal', 'IAC Harmonia' e 'IAC Formoso' foram os genótipos menos consumidos, o que indica antixenose à alimentação. No teste sem chance de escolha, todos os genótipos (exceto 'IAPAR 57') expressaram níveis moderados de antixenose à alimentação de larvas de C. includens.

Termos para indexação: feijão-comum, resistência de plantas hospedeiras, não preferência, mecanismos de resistência, lagarta-falsa-medideira.

\section{Introduction}

Brazil is considered to be the largest producer and consumer of common bean worldwide (Cabral et al., 2011). Bean production in Brazil in 2013/2014 was 3,511.1 million tons (Acompanhamento..., 2014).
Although Brazil is a great producer of this legume, the attack of various insect pests on bean plants compromises productivity in the field (Wendt $\&$ Carvalho, 2006). Among these insect pests, the soybean looper, Chrysodeixis includens (Walker) (Lepidoptera: Noctuidae), has been considered to be

Pesq. agropec. bras., Brasília, v.50, n.6, p.450-458, jun. 2015

DOI: 10.1590/S0100-204X2015000600003 
of growing importance for bean cultivation, due to damage caused during the last harvests (Baldin et al., 2014). Attack from C. includens causes characteristic holes on leaf surface, mainly in the more developed leaves. In the fourth instar, caterpillars can pierce the leaves, consuming large areas, keeping only main veins intact, which confers a characteristic lacy aspect to the attacked leaves (Sinclair et al., 1997). In soybean plants, one individual of $C$. includens can consume between 80 and $200 \mathrm{~cm}^{2}$ (Bueno et al., 2011).

For soybean crop, the control of infestations of $C$. includens has been performed mainly through spraying with synthetic insecticides. However, the understanding that this practice contributes to the agroecosystem unbalance (Bernardi et al., 2012) encouraged studies on complementary methods of control which offer efficiency and, at the same time, are less destructive to the environment. In this sense, the use of resistant cultivars stands out as a valuable strategy against insect pests (Smith \& Clement, 2012). In many cases, varietal resistance has shown significant efficiency, reducing pest populations to rates below the level of economic injury, consequently reducing the production costs (Smith, 2005). Plant resistance can be expressed through three different mechanisms: antixenosis, antibiosis, and tolerance (Smith \& Clement, 2012). Antixenosis is the resistance mechanism employed by plants to deter or reduce colonization by insects. In general, insects orient themselves on plants for feeding, oviposition sites, or shelter. However, due to specific characteristics, attacked plants may not be utilizable and may inhibit the insects. In some cases, the antixenotic characteristics of a plant do not allow insects to colonize it. Sometimes the antixenosis mechanism is so effective that insects starve and die (Smith, 2005).

Although plant resistance is an important strategy for integrated pest management (IPM), until present, no study on common bean genotypes resistant to C. includens could be find. However, considering the importance of this crop to Brazilian population, and the high damage potential of soybean looper caterpillar to the culture, the selection of more resistant genotypes to insect attack becomes highly desirable. The results may help producers in the choice of less susceptible genotypes to insect attack. Additionally, these data may also be useful for improvement programs of common bean focusing on resistance to defoliating pests.
The objective of this work was to evaluate 59 bean genotypes for resistance to Chrysodeixis includens.

\section{Materials and Methods}

The work was developed in the Laboratório de Resistência de Plantas a Insetos e Plantas Inseticidas (Larespi) and in greenhouses of the Departamento de Proteção de Plantas, Universidade Estadual Paulista (Unesp), Botucatu, SP, Brazil, from 2012 to 2013. In the laboratory $\left(26 \pm 2^{\circ} \mathrm{C}, 65 \pm 10 \% \mathrm{RH}, 14 \mathrm{~h}\right.$ light: $10 \mathrm{~h}$ dark photophase), attractiveness and consumption assays were carried out with $C$. includens larvae. In greenhouse, the assays were conducted with adults. The evaluated common bean genotypes (59) (Table 1) were supplied by Instituto Agronômico (IAC, Campinas, SP, Brazil), and are part of the active germplasm bank of the institution.

A colony of $C$. includens was initiated from eggs that came from a laboratory colony maintained by DuPont (Paulínia, SP, Brazil). This colony was maintained in an artificial diet, according to the methodology proposed by Parra et al. (2009), with adaptations.

The plants used in the experiments were maintained in a greenhouse ( $3 \mathrm{~m}$ long x $2 \mathrm{~m}$ wide $\times 2 \mathrm{~m}$ high), and they were grown in polyethylene plastic pots $(2.5$ L) filled with a substrate of a mixture of soil (Oxisol), washed coarse sand, and organic matter (corral manure) at 1:1:1. Plant fertilization was performed according to Ambrosano et al. (1997). Other necessary cultural practices were also followed (irrigation and thinning). All assays were performed with plants in the $\mathrm{V}_{4}$ phenological stage (Fernández et al., 1986).

A preliminary free-choice test was carried out in a greenhouse with the 59 bean genotypes, which were divided into three groups according to the color of their leaves (Table 1). Leaf color was determined according to the scale of minimum bean morphological descriptors items suggested by the Ministério da Agricultura Pecuária e Abastecimento (MAPA), used for the protection of plant varieties (Brasil, 2014). The genotypes 'Pérola' and 'IAC Formoso' were included as controls in all three groups, as these cultivars are susceptible to defoliators.

In this assay, plants were randomly placed in a circle inside metal cages $(2.5 \times 3.0 \times 2.5 \mathrm{~m})$, covered at the top with plastic sheeting and shade cloth $(30 \%)$, and protected on the sides with white anti-aphid screens. 
Table 1. Name, access number at BAG IAC, and characteristics (genealogy or source) of bean genotypes of dark, medium, and light color leaf.

\begin{tabular}{|c|c|c|}
\hline Name & Access BAG IAC & Characteristics (genealogy or source) \\
\hline \multicolumn{3}{|r|}{ Dark colored leaves (group 1) } \\
\hline Arcelina 1 & IAC 583 & Source of resistance to bruchids \\
\hline Arcelina 2 & IAC 584 & Source of resistance to bruchids \\
\hline Arcelina 3 & IAC 585 & Source of resistance to bruchids \\
\hline Arcelina 4 & IAC 586 & Source of resistance to bruchids \\
\hline 'IPR Tangará' & IAC 2174 & LP95 92 x 'Pérola' \\
\hline RAZ 49 & IAC 816 & Probable crossing with Arc 1 \\
\hline RAZ 55 & IAC 819 & Probable crossing with Arc 1 \\
\hline 'Pérola' & IAC 832 & Selection in 'Aporé' \\
\hline 'IAC Milênio' (Lineage C4-7-7-2-2) & IAC 2175 & Gen 96A98 x (Pérola x Ouro Negro) \\
\hline 'BRS Esteio' (CNFC 10104) & IAC 2176 & Crossing between lineages FT85 113 / POT 51 \\
\hline 'BRS Pontal' & IAC 1186 & BZ 3836 x FEB 166 x NA 910523 \\
\hline 'BRS Requinte' & IAC 1187 & 'Carioca MG' x POT 94 x NA 910523 \\
\hline 'Caneludo' & IAC 907 & Crioula genotype \\
\hline CV 48 & IAC 1711 & Line from Federal University of Lavras \\
\hline 'FT Bonito' & IAC 834 & Source of moderate resistance to powdery mildew, rust, anthracnose, angular leaf spot, bacteriosis and golden mosaic \\
\hline 'IAPAR 14' & IAC 604 & Crossing between ('Carioca 99' x 'Great Northern Nebraska 1 Sel. 27') x BAT 614 \\
\hline 'IAPAR 57' & IAC 1010 & 'Porrillo Sintético'/'Aeté 1 38'//Cena 83 1/3/IAPAR BAC 32 \\
\hline 'Rubi' & IAC 877 & Crioula cultivar selected within 'Pérola' \\
\hline 'IPR 139' ('Juriti Claro') & IAC 2177 & Selection from 'IPR Juriti' \\
\hline 'Mar 2' & IAC 625 & Source of resistance to angular leaf spot \\
\hline \multicolumn{3}{|r|}{ Medium colored leaves (group 2) } \\
\hline 'IPR Uirapuru' & IAC 834 & BAC29/PR1711/3/NEP2/2/Puebla173/Icapijao \\
\hline TU & IAC 637 & Source of resistance to anthracnose \\
\hline TO & IAC 638 & Source of resistance to anthracnose \\
\hline 'IAPAR 72' & IAC 69 & Selected from the line MD 706 \\
\hline 'Carioca Comum' & IAC 827 & Selected cultivar by the farmer. Unknown genitors. \\
\hline 'Brancão Argentino' & IAC 1034 & White beans from Argentina. Unknown genitors. \\
\hline 'Flor de Mayo' & IAC 619 & Unknown genitors \\
\hline 'IPR Siriri' & IAC 1709 & Crossing between 'IAPAR 31' and 'IAC Akitã' \\
\hline 'IPR Campos Gerais' & IAC 1708 & Source of resistance to rust and powdery mildew \\
\hline 'IPR Eldorado' & IAC 1780 & From 'IAPAR 72' \\
\hline A 449 & IAC 621 & Source of resistance to anthracnose \\
\hline 'BRS Cometa' & IAC 1783 & A 769 / 4 / EMP 250 /// A 429 / XAN 252 // C 8025 / G 4449 /// WAF 2 / A 55 // GN 31 / XAN 170 \\
\hline 'BRS Horizonte' & IAC 1782 & EMP 250 / 4 / A 769 /// A 429 / XAN 252 // Pinto VI 114 \\
\hline 'BRSMG Talismã' & IAC 2173 & $\begin{array}{l}\text { Recurrent selection involving genotypes BAT 477, 'IAPAR 14', FT } 84 \text { 29, 'Jalo EEP', A 252, A 77, 'Ojo de Liebre', } \\
\text { 'ESAL 645', 'Pintado', 'Carioca', 'ESAL 645', P 85, P 103, H 4, AN910522, 'ESAL 624', 'Carioca MG' }\end{array}$ \\
\hline HFS 465-63-1 & IAC 630 & Old cultivar resistant to Fusarium \\
\hline 'IAPAR 81' & IAC 672 & A248/EMP117/4/Bat 93/2/carioca Sel.99/G.N. Nebraska 1\#27/3/ Sel Aroana \\
\hline 'Rudá' & IAC 833 & 'Carioca 80' / 'Rio Tibagi' \\
\hline G2333 & IAC 645 & Crioula cultivar resistant to anthracnose \\
\hline 'IAPAR 44' & IAC 582 & (IAPAR BAC 2 x RAI 12) x ('Rio Tibagi 2' x Cornell 49 242) \\
\hline \multicolumn{3}{|r|}{ Light colored leaves (group 3) } \\
\hline 'IAC Una' & IAC 707 & Source of resistance to anthracnose (Dor 41 x H1178 100) \\
\hline 'IAC Alvorada' & IAC 1180 & $\{$ ('IAC Carioca Pyatã'. A686) x [('IAC Maravilha' G2338). ('IAC Maravilha'. And277)]\} x L317 1 \\
\hline 'IAC Boreal' & IAC 1698 & 'IAC Carioca Aruã' x CAL 143 \\
\hline 'IAC Jabola' & IAC 1703 & Access Jabola from Bag IAC x 'IAC Carioca Tybatã' \\
\hline 'IAC Esperança' & IAC 1701 & Jalo Itararé x 'IAC Carioca Eté' \\
\hline 'IAC Imperador' & IAC 2179 & 60 days ('IAC Carioca Eté' x 'Carioca Precoce') \\
\hline 'BRSMG Madrepérola' & IAC 2181 & Crossing between lines NA 5126660 and AN 730031 \\
\hline H96A28 P4-1-1-1 & IAC 2182 & (Vax1 x 'IAC Carioca Aruã') x ('IAC Carioca Akytã' x 'IAPAR 14') x A686 \\
\hline H96A102-1-1-1-52 & IAC 2183 & ('IAC Carioca Aruã' x G5686) x (Xan 251. 'IAC Carioca Akytã') x ('IAC Carioca Pyatã' x Mar 1) x 'Pérola' \\
\hline 'IAC Carioca Aruã' & IAC 709 & $(10771.122) \times[(\mathrm{H} 5380$ 41.A156) $\mathrm{x}(\mathrm{H} 538041 . \mathrm{AB} 136)]$ \\
\hline 'IAC Formoso' & IAC 2178 & Gen 96A28P4 $1111 \times$ CNFC9484 \\
\hline 'IAC Harmonia' & IAC 1697 & 'IAC Carioca Aruã' x 'Iraí' \\
\hline 'IAC Ybaté' & IAC 1193 & Emp81 x H853 502 \\
\hline 'IAC Carioca Eté' & IAC 837 & L933 x LM30630 122 \\
\hline 'BRSMG Majestoso' & IAC 2180 & 'Ouro Negro' x 'Pérola' \\
\hline 'IAPAR 31' & IAC 597 & IAPAR BAC 4 / RAI 46//IAPAR BAC2 / 'IGUAÇÚ' /3/ BAT 93/ IAPAR BAC 4 \\
\hline 'Mex 279' & IAC 646 & Crioula \\
\hline Wild Mex & IAC 789 & Wild cultivar \\
\hline Access $1055(87 J P 12)$ & IAC 1055 & Crioula cultivar (possible origin Phaseolus lunatus Linnaeus) \\
\hline 'Carioca Lustroso' & IAC 1014 & Crioula cultivar \\
\hline
\end{tabular}

Pesq. agropec. bras., Brasília, v.50, n.6, p.450-458, jun. 2015 
Pots containing the plants were spaced approximately $15 \mathrm{~cm}$ apart, in order to avoid contact between plants. Each cage was considered a replicate, following a randomized block design, with four replicates for each group. The cages were infested with two pairs of C. includens per genotype.

Oviposition was evaluated four days after infestation, by visually counting the number of eggs on all plant leaves (Campos et al., 2010). After counting, the oviposition preference index (OPI) was determined by the equation OPI $=[(\mathrm{T}-\mathrm{P}) /(\mathrm{T}+\mathrm{P})] 100$ (Baldin et al., $2005,2007)$ in which: T, no. of eggs in the evaluated treatment and P, no. of eggs in the standard genotype. 'IAC Formoso' (most susceptible) was adopted as a standard for genotype classification.

Free and no-choice oviposition tests, carried out in sequence, used 14 genotypes selected from the preliminary test. Twelve genotypes (four from each group) with the lowest oviposition rates, which means they are promising for resistance, were chosen: Arcelina 4, Arcelina 1, 'IAPAR 57', 'Rubi' (from group 1); 'Flor de Mayo', 'IAPAR 81', 'BRS Horizonte', 'IAPAR 44' (from Group 2); 'IAC Boreal', 'IAC Jabola', 'IAC Harmonia', H96A102-1-1-1-52 (from Group 3). Genotypes 'IAC Formoso' and 'Pérola' were kept as susceptible commercial standards.

In free-choice tests, oviposition was evaluated in cages identical to those used during the preliminary test. In this case, plants from the 14 genotypes formed only one group. The methodology used for the evaluation of oviposition preference was the same described for the previous experiment, releasing two pairs of $C$. includens per genotype. A randomized block design was carried out with 14 treatments (genotypes) and seven replicates (one cage represented one replicate).

For the no-choice test, individual cages $(30 \mathrm{~cm}$ diameter $\times 70 \mathrm{~cm}$ high) covered with organdy fabric were used around potted plants $\left(\mathrm{V}_{4}\right.$ stage $)$ of the different genotypes. Inside the cages, two pairs of $C$. includens per genotype were released. The infestations were maintained for four days until the evaluation, according to the methodology described in the previous experiments (Campos et al., 2010). A completely randomized design was performed with 14 treatments (genotypes) and seven replicates (each individualized plant represented one replicate).

Plant attractiveness was evaluated in the laboratory (under already described conditions), in free-choice conditions for third-instar $C$. includens larvae, with leaf discs of the 14 selected genotypes. Therefore, two third-instar larvae per genotype were released inside a metallic circular arena (50 $\mathrm{cm}$ diameter $\mathrm{x} 4 \mathrm{~cm}$ height) containing the leaf disks $\left(3.90 \mathrm{~cm}^{2}\right)$. Oncelarvae reached the third instar, they were subjected to a 12-hour-fast before the installation of the assay. Third-instar larvae were chosen for being less sensitive than first- and second-instar ones, and also for consuming significant amount of leaf area (Schlick-Souza et al., 2011). The number of larvae in the leaf disks of each genotype was counted at 15,30, and $60 \mathrm{~min}$, at 2, 3,6 and 12 hours after release.

At the end of evaluations, the attractiveness index (AI) was calculated by using the equation $\mathrm{AI}=2 \mathrm{~T} /$ $(\mathrm{T}+\mathrm{P})$ (Lin et al., 1990). 'IAC Formoso' was also adopted as standard for the classification of genotypes. A randomized complete block design was used with 14 treatments (genotypes) and ten replicates (metallic arenas).

Leaf disk consumption by $C$. includens third-instar larvae was evaluated in a free-choice test. Thus, two third-instar larvae per genotype were released inside metallic circular arenas (the same used for the attractiveness), containing the leaf disks $\left(3.90 \mathrm{~cm}^{2}\right)$ of the 14 genotypes. The arenas were observed until some leaf disks of the different genotypes in one of these areas were consumed by nearly $90 \%$, when the test has ended. The remaining disks were taken in identifiable paper bags, which were then placed in an oven at $60{ }^{\circ} \mathrm{C}$, for one day, in order to obtain the dry mass (Boiça Junior et al., 2013). Together with the disks remaining at the end of the experiments, another ten discs (controls) of different genotypes were also dried and served as an aliquot for determining the consumed dry mass (Boiça Junior et al., 2013). Dry mass of the leaf disks was weighted in an analytical balance with $0.0001 \mathrm{~g}$ precision, model Marte AY 220 (Shimadzu Corporation, Kyoto, Japan). A randomized complete block design was used, with 14 treatments (genotypes) and ten replicates (metallic arenas).

Leaf consumption was also evaluated in no-choice tests. Therefore, two third-instar larvae were individually placed on leaf disks of the different genotypes inside Petri dishes $(8 \times 2 \mathrm{~cm})$. Evaluations followed the same criteria of the free-choice test. A completely randomized design was carried out with 14 treatments (genotypes) and ten replicates 
(Petri dishes). Before initializing the two types of test, third-instar larvae were subjected to a 12-hour-fast.

Data were subjected to analysis of variance by F-test, and checked for normality using the Shapiro-Wilk test, and for homogeneity using the Levene test. When treatment effects were significant at 5\% probability, means were separated using Scott-Knott and Fisher Least Significant Difference (LSD) tests, using the procedure Proc Mixed of SAS software (SAS Institute Inc., Cary, NC, USA).

\section{Results and Discussion}

Based on the oviposition preference index for the genotypes of group 1, 'FT Bonito', Arcelina 1, 'BRS Esteio', 'Rubi', Arcelina 4, 'IAPAR 57', 'Mar 2', 'Caneludo', 'RAZ 49' and 'RAZ 55' were deterrents in comparison to the susceptible standard 'IAC Formoso', while the other genotypes were considered neutral to oviposition of $C$. includens (Figure 1). For the Group 2, the lineage TO, and the genotypes 'Flor de Mayo', 'IAPAR 44', 'IAPAR 81', 'BRS Horizonte', HFS-465-63-1, G2333, 'IPR Uirapuru', 'IPR Siriri', and Rudá were classified as deterrents; the other genotypes were considered to be neutral to oviposition compared to 'IAC Formoso'. For the Group 3, only 'IAC Boreal' was deterrent to oviposition; and 'IAC Carioca Eté' was considered to be a stimulant for oviposition compared to the standard 'IAC Formoso'; the other genotypes were classified as neutral.

Analyzing the oviposition behavior of $C$. includens on genotypes of different groups (variable coloration of the leaves), it was observed that adult insects showed loweroviposition preference (plant's greater deterrence) for genotypes with dark green leaves (group 1) and medium (group 2) in relation to those with lighter green leaves (group 3). Although no studies were found on the host selection by adults of $C$. inludens on common bean, differently from the present study, Mercader et al. (2007) reported a higher oviposition preference by Papilio glaucus L. (Lepidoptera: Papilionidae) on dark green leaves of Fraxinus americana L., Liriodendron tulipifera L., and Prunus serotina Ehrh., than for light-green or yellowish-green leaves. Color intensity of the vegetable substrate is one of the extrinsic factors positively or negatively affecting the selection of host plants by phytophagous insects (Mercader \& Scriber,
2007). This could explain the behavior observed for C. includens in the present work.

In addition, it was cannot disregard the potential action of undesirable volatiles (allomones) in different genotypes, which may affect host selection by insects. According to Cunningham \& Zalucki (2014), the interaction between visual and olfactory cues may
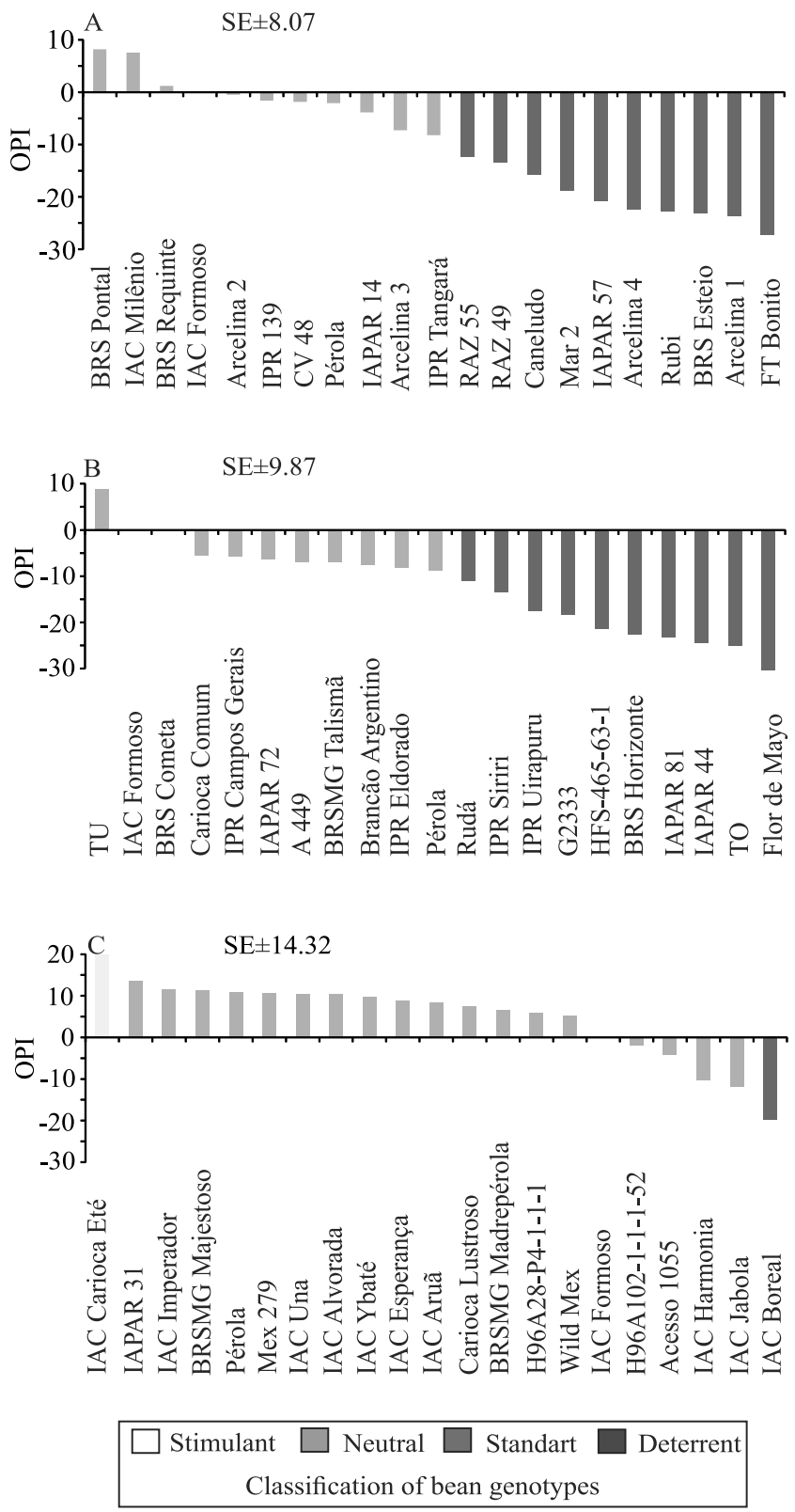

Figure 1. Oviposition preference index (OPI), and classification of bean genotypes - group 1, dark leaves (A); group 2, medium leaves (B); and group 3, light leaves (C) -, as a function of oviposition of Chrysodeixis includens, in free choice test, in greenhouse. SE, standard error. 
be important in evoking oviposition responses. In the present work, chemical characterization of volatiles present in the plants of the different genotypes was not carried out. However, Bruce et al. (2005) and Benda et al. (2011) reported that several species of Lepidoptera are able to recognize specific kairomones in preferred hosts. A highly polyphagous insect may be capable of classifying odors in plants, such that the majority of odors are responded to as good, poor, and non-hosts (Cunningham, 2012). Although chemical analysis of volatiles has not been the object of this study, in the future, the characterization of these less infested genotypes would be desirable, in order to identify the mechanisms involved.

As to the oviposition of $C$. includens in the free-choice test, there was no difference for the mean number of eggs deposited on the selected genotypes (Table 2). Yet, in the no-choice test, the genotypes 'IAC Jabola' (45.57), Arcelina 1 (51.71), 'IAC Boreal' (70.43), 'Flor de Mayo' (71.71) and 'IAC Formoso' (82.00) showed the lowest means of eggs, differing from 'BRS Horizonte' (316.86) and 'IAPAR 57' (263.57).

Kidd \& Orr (2001) evaluated the oviposition of C. includens on soybean and kudzu (Pueraria montana Lour.), in free-choice and no-choice tests, and observed a higher number of eggs on soybean leaves (68.5 and 570.9 , respectively), compared to kudzu leaves (44.0 and 325.7, respectively). Independent of the host, the authors reported a higher number of eggs obtained in no-choice tests. In the present research, this kind of behavior was also observed for $C$. includens on 'BRS Horizonte' (316.86), 'IAPAR 57' (263.57), and 'Pérola' (209.43), which showed higher numbers of eggs in the no-choice tests. In free-choice test, adult lepidopterans do not respond to all host plants equally, and the females may show greater preference for certain plants; in no-choice test, when the insect is maintained isolated on a host plant, it may also attack the plant that would normally not be preferred, causing considerable damage (Cunningham \& Zalucki, 2014).

Based on the average attractiveness index of third-instar larvae of $C$. includens, the genotypes H96A102-1-1-1-52, 'Flor de Mayo' and Arcelina 4 were classified as repellents in comparison to 'IAC Formoso', which is the susceptible commercial standard (Figure 2). 'IAPAR 57', 'IAPAR 44', 'Pérola', 'Rubi', 'IAC Harmonia', 'IAC Jabola', 'BRS Horizonte', and 'IAC Boreal' showed to be neutral, and the genotypes
Arcelina 1 and 'IAPAR 81' were considered attractive, in comparison to the susceptible standard. The lower attractiveness of leaf disks of H96A102-1-1-1-52, 'Flor de Mayo' and Arcelina 4 indicates that these genotypes showed secondary repellent substances generally associated with antixenosis. Although there are no reports about repellency or feeding deterrence associated with these genotypes, the repellent effect of certain plants on insects may occur, due to the volatilization of chemical substances from the leaves (War et al., 2011), which negatively affects insect preference.

As to leaf consumption by third-instar larvae, in free-choice tests (Figure 3), the genotypes Arcelina 4, 'BRS Horizonte', 'Pérola', H96A102-1-1-1-52, 'IAC Boreal', 'IAC Harmonia' and 'IAC Formoso' showed the lowest means, suggesting the occurrence of antixenosis to feeding.

The lowest insect attraction to leaf disks of some genotypes was expected to correspond to the lowest leaf consumption of those disks. However, such a situation did not occur in all materials. For instance, 'Flor de Mayo' was lightly attractive (Figure 2), but revealed a high consumption index. This suggests that the biggest attraction of the insect by the host plant does not necessarily reveal to be the appropriate food for larval development (Von Mérey et al., 2013). As reported

Table 2. Mean \pm standard error number of eggs of Chrysodeixis includens on leaves of bean genotypes, in free and no-choice tests, in greenhouse ${ }^{(1)}$.

\begin{tabular}{lcc}
\hline Genotype & \multicolumn{2}{c}{ Number of eggs } \\
\cline { 2 - 3 } & \multicolumn{1}{c}{ Free choice test } & No-choice test \\
\hline 'BRS Horizonte' & $203.14 \pm 42.64$ & $316.86 \pm 69.74 \mathrm{a}$ \\
'IAPAR 57' & $205.14 \pm 42.85$ & $263.57 \pm 96.18 \mathrm{ab}$ \\
'Pérola' & $171.14 \pm 36.49$ & $209.43 \pm 69.91 \mathrm{abc}$ \\
Arcelina 4 & $216.00 \pm 41.93$ & $204.00 \pm 113.38 \mathrm{abc}$ \\
'IAC Harmonia' & $234.86 \pm 30.43$ & $178.71 \pm 64.28 \mathrm{abc}$ \\
'IAPAR 81' & $195.57 \pm 32.01$ & $126.43 \pm 44.27 \mathrm{bc}$ \\
H96A102-1-1-1-52 & $191.86 \pm 38.31$ & $112.86 \pm 53.75 \mathrm{bc}$ \\
'IAPAR 44' & $198.71 \pm 29.74$ & $105.29 \pm 22.58 \mathrm{bc}$ \\
'Rubi' & $183.14 \pm 22.94$ & $95.43 \pm 67.47 \mathrm{bc}$ \\
'IAC Formoso' & $193.14 \pm 33.13$ & $82.00 \pm 35.89 \mathrm{c}$ \\
'Flor de Mayo' & $122.43 \pm 32.80$ & $71.71 \pm 41.34 \mathrm{c}$ \\
'IAC Boreal' & $156.29 \pm 35.05$ & $70.43 \pm 32.03 \mathrm{c}$ \\
Arcelina 1 & $183.43 \pm 41.36$ & $51.71 \pm 16.73 \mathrm{c}$ \\
'IAC Jabola' & $151.00 \pm 30.96$ & $45.57 \pm 31.22 \mathrm{c}$ \\
\hline P & 0.1570 & 0.0406 \\
\hline (1)Means followed by equal letters, in the columns, are not significantly \\
different, by LSD test at 5\% probability.
\end{tabular}

Pesq. agropec. bras., Brasília, v.50, n.6, p.450-458, jun. 2015 DOI: 10.1590/S0100-204X2015000600003 
by Von Mérey et al. (2013) and Cunningham (2012), volatile organic compounds emitted by plants were attractive to larvae, but the exposure to volatiles decreased the growth rate of caterpillars, possibly due to the lower leaf consumption. This may explain the divergences found between very attractive materials and few consumed ones or the inverse of this.

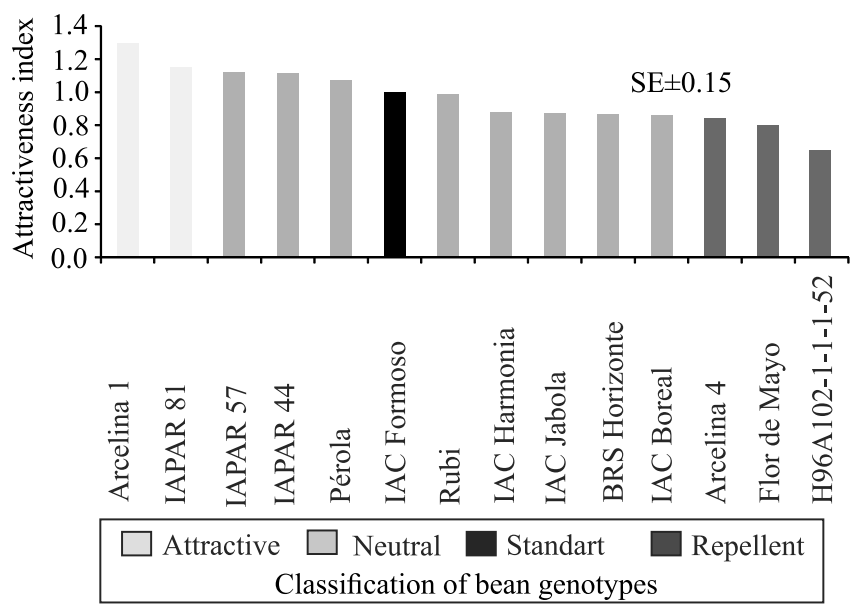

Figure 2. Attractiveness index and classification of bean genotypes for third instar larvae of Chrysodeixis includens, in free choice test under laboratory conditions $\left(26 \pm 2^{\circ} \mathrm{C}\right.$, $65 \pm 10 \% \mathrm{RH}, 14$-hour-photophase). SE, standard error.

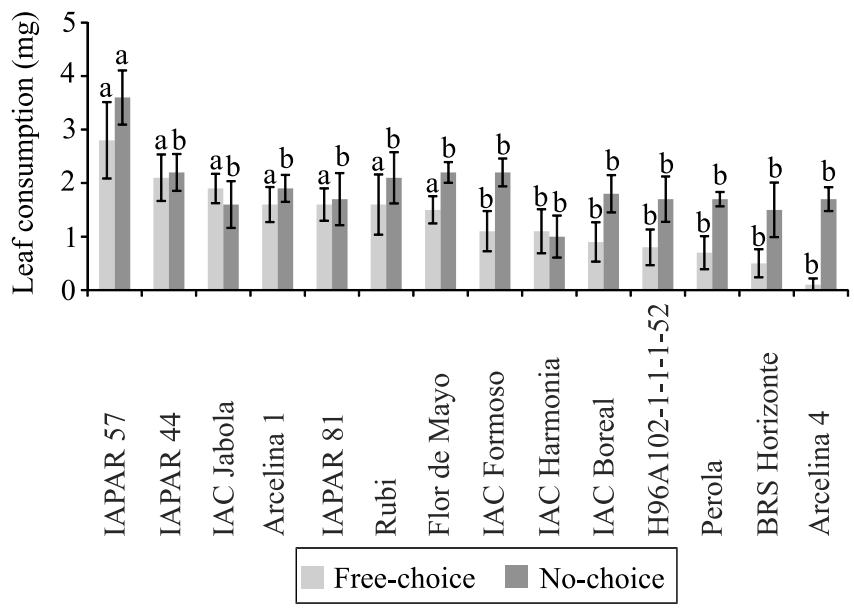

Figure 3. Mean \pm standard error of leaf consumption by third instar larvae of Chrysodeixis includens, in free and no-choice tests, under laboratory conditions $\left(26 \pm 2^{\circ} \mathrm{C}, 65 \pm 10 \% \mathrm{RH}\right.$, 14-hour photophase). Means followed by the same letter, in the columns of the same color, are not significantly different, by Scott Knott test at 5\% probability.
Based on the results for the leaf consumption in no-choice test (Figure 3), all genotypes differed from 'IAPAR 57', which was the most consumed plant by larvae. Lower consumption of the materials is possibly due to the presence of deterrent substances to feeding. Through their sensory organ, as gustatory semiochemicals, the phytophagous insects have the ability to select a host plant which, in turn, may show an attractive or deterrent effect on insect feeding (Bruce et al., 2005). Souza et al. (2012) found lower leaf consumption by Lepidoptera larvae, possibly due to morphological and chemical factors intrinsic to them which also provide degrees of resistance to insects.

Evaluating consumption by larvae of $C$. includens on two soybean genotypes, Reynolds et al. (1984) found a growth reduction in insects feeding on PI 227687. These authors reported that this fact is related to the presence of deterrent substances in the plant or to the plant failing to feeding stimuli. Hwang et al. (2008) affirm that insect growth is directly correlated with nutrient input, once Lepidoptera larvae fed high nutrient food showed faster growth rates than those fed nutrient-poor food.

Because of the damage potential that $C$. includens shows for bean cultivation, the results obtained with the evaluated materials, in the present study, can help genetic improvement programs focusing on this pest management. In the future, more detailed assessments as to the chemical, physical, and morphological aspects of leaves of bean genotypes will be addressed aiming to identify the main causes associated with antixenosis, showed by some of the evaluated genotypes in this work.

\section{Conclusions}

1. 'IAC Jabola', Arcelina 1, 'IAC Boreal', 'Flor de Mayo', and 'IAC Formoso' express antixenosis resistance to $C$. includens oviposition.

2. In free-choice conditions, Arcelina 4, 'BRS Horizonte', 'Pérola', H96A102-1-1-1-52, 'IAC Boreal', 'IAC Harmonia', and 'IAC Formoso' are less consumed and express antixenosis for feeding to third-instar larvae of $C$. includens.

3. In no-choice conditions, all genotypes (except for 'IAPAR 57') express moderate levels of antixenosis to feeding against $C$. includens larvae. 


\section{Acknowledgments}

To Coordenação de Aperfeiçoamento de Pessoal de Nível Superior (Capes) and to Conselho Nacional de Desenvolvimento Científico e Tecnológico (CNPq), for fellowship grantings; to Dr. Sinval Silveira Neto, Escola Superior de Agricultura Luiz de Queiroz, for the identity confirmation of Chrysodeixis includens.

\section{References}

ACOMPANHAMENTO da safra brasileira de grãos: safra 2013/2014: sétimo levantamento abril/2014. Brasília: Companhia Nacional de Abastecimento, 2014. Disponível em: <http://www. bcsp.com.br/Editais2014/Setimo\%20Levantamento\%20Safra $\% 20$ 1314.pdf>. Acesso em: 22 jun. 2014.

AMBROSANO, E.J.; TANAKA, R.T.; MASCARENHAS, H.A.A.; VAN RAIJ, B.; QUAGGIO, J.A.; CANTARELLA, H. Leguminosas e oleaginosas. In: VAN RAIJ, B.; CANTARELLA, H.; QUAGGIO, J.A.; FURLANI, A.M.C. (Ed.). Recomendações de adubação e calagem para o Estado de São Paulo. 2.ed. Campinas: Instituto Agronômico, 1997. p.189-203. (IAC. Boletim técnico, 100).

BALDIN, E.L.L.; LOURENÇÃO, A.L.; SCHLICK-SOUZA, E.C. Outbreaks of Chrysodeixis includens (Walker) (Lepidoptera: Noctuidae) in common bean and castor bean in São Paulo State, Brazil. Bragantia, v.73, p.458-465, 2014. DOI: 10.1590/1678-4499.0277.

BALDIN, E.L.L.; SOUZA, D.R.; SOUZA, E.S.; BENEDUZZI, R.A. Controle da mosca-branca com extratos vegetais, em tomateiro cultivado em casa-de-vegetação. Horticultura Brasileira, v.25, p.602-606, 2007. DOI: 10.1590/S0102-05362007000400022.

BALDIN, E.L.L.; VENDRAMIM, J.D.; LOURENÇÃO, A.L. Resistência de genótipos de tomateiro à mosca-branca Bemisia tabaci (Gennadius) biótipo B (Hemiptera: Aleyrodidae). Neotropical Entomology, v.34, p.435-441, 2005. DOI: 10.1590/ S1519-566X2005000300012.

BENDA, N.D.; BROWNIE, C.; SCHAL, C.; GOULD, F. Field observations of oviposition by a specialist herbivore on plant parts and plant species unsuitable as larval food. Environmental Entomology, v.40, p.1478-1486, 2011. DOI: 10.1603/EN09335.

BERNARDI, O.; MALVESTITI, G.S.; DOURADO, P.M.; OLIVEIRA, W.S.; MARTINELLI, S.; BERGER, G.U.; HEAD, G.P.; OMOTO, C. Assessment of the high-dose concept and level of control provided by MON 87701 x MON 89788 soybean against Anticarsia gemmatalis and Pseudoplusia includens (Lepidoptera: Noctuidae) in Brazil. Pest Management Science, v.68, p.1083-1091, 2012. DOI: 10.1002/ps.3271.

BOIÇA JÚNIOR, A.L.; JANINI, J.C.; SOUZA, B.H.S.; RODRIGUES, N.E.L. Efeito de cultivares de repolho e doses de extrato aquoso de nim na alimentação e biologia de Plutella xylostella (Linnaeus) (Lepidoptera: Plutellidae). Bioscience Journal, v.29, p.22-31, 2013.
BRASIL. Ministério da Agricultura, Pecuária e Abastecimento. Formulários para proteção de cultivares. Disponível em: $<$ http://www.agricultura.gov.br/vegetal/registros-autorizacoes/ protecao-cultivares/formularios-protecao-cultivares $>$. Acesso em: 20 out. 2014.

BRUCE, T.J.A.; WADHAMS, L.J.; WOODCOCK, C.M. Insect host location: a volatile situation. Trends in Plant Science, v.10, 2005. DOI: 10.1016/j.tplants.2005.04.003.

BUENO, R.C.O. de F.; BUENO, A. de F.; MOSCARDI, F.; PARRA, J.R.P.; HOFFMANN-CAMPO, C.B. Lepidopteran larva consumption of soybean foliage: basis for developing multiple-species economic thresholds for pest management decisions. Pest Management Science, v.67, p.170-174, 2011. DOI: $10.1002 / \mathrm{ps} .2047$.

CABRAL, P.D.S.; SOARES, T.C.B.; LIMA, A.B.P.; SOARES, Y.J.B.; SILVA, J.A. da. Análise de trilha do rendimento de grãos de feijoeiro (Phaseolus vulgaris L.) e seus componentes. Revista Ciência Agronômica, v.42, p.132-138, 2011. DOI: 10.1590/ S1806-66902011000100017.

CAMPOS, A.P.; BOIÇA JUNIOR, A.L.; RIBEIRO, Z.A. Não preferência para oviposição e alimentação de Spodoptera frugiperda (J. E. Smith, 1797) (Lepidoptera: Noctuidae) por cultivares de amendoim. Arquivos do Instituto Biológico, v.77, p.251-258, 2010.

CUNNINGHAM, J.P. Can mechanism help explain insect host choice? Journal of Evolutionary Biology, v.25, p.244-251, 2012. DOI: $10.1111 /$ j.1420-9101.2011.02435.x.

CUNNINGHAM, J.P.; ZALUCKI, M.P. Understanding Heliothine (Lepidoptera: Heliothinae) pests: what is a host plant? Journal of Economic Entomology, v.107, p.881-896, 2014. DOI: 10.1603/ EC14036.

FERNÁNDEZ, F.; GEPTS, P.; LÓPEZ, M. Etapas de desarrollo de la planta de frijol común (Phaseolus vulgaris L.). Cali: Centro Internacional de Agricultura Tropical, 1986. 34p.

HWANG, S.-Y.; LIU, C.-H.; SHEN, T.-C. Effects of plant nutrient availability and host plant species on the performance of two Pieris butterflies (Lepidoptera: Pieridae). Biochemical Systematics and Ecology, v.36, p.505-513, 2008. DOI: 10.1016/j.bse.2008.03.001.

KIDD, K.A.; ORR, D.B. Comparative feeding and development of Pseudoplusia includens (Lepidoptera: Noctuidae) on kudzu and soybean foliage. Annals of the Entomological Society of America, v.94,p.219-225,2001.DOI: 10.1603/0013-8746(2001)094[0219:CF ADOP]2.0.CO;2.

LIN, H.; KOGAN, M.; FISCHER, D. Induced resistance in soybean to the Mexican bean beetle (Coleoptera: Coccinelidae): comparisons of inducing factors. Environmental Entomology, v.19, p.1852-1857, 1990. DOI: 10.1093/ee/19.6.1852.

MERCADER, R.J.; KRUITHOFF, R.; SCRIBER, J.M. Do generalist tiger swallowtail butterfly females select dark green leaves over yellowish - or reddish-green leaves for opposition? Great Lakes Entomologist, v.40, p.29-42, 2007.

MERCADER, R.J.; SCRIBER, J.M. Diversification of host use in two polyphagous butterflies: differences in oviposition specificity or host rank hierarchy? Entomologia Experimentalis et Applicata, v.125, p.89-101, 2007. DOI: 10.1111/j.1570-7458.2007.00598.x. 
PARRA, J.R.P.; PANIZZI, A.R.; HADDAD, M.L. Índices nutricionais para medir consumo e utilização de alimentos por insetos. In: PANIZZI, A.R.; PARRA, J.R.P. (Ed.). Bioecologia e nutrição de insetos: base para o manejo integrado de pragas. Brasília: Embrapa Informação Tecnológica, 2009. p.38-90.

REYNOLDS, G.W.; SMITH, C.M.; KESTER, K.M. Reductions in consumption, utilization, and growth rate of soybean looper (Lepidoptera: Noctuidae) larvae fed foliage of soybean genotype PI 227687. Journal of Economic Entomology, v.77, p.1371-1375, 1984. DOI: $10.1093 /$ jee/77.6.1371.

SCHLICK-SOUZA, E.C.; BALDIN, E.L.L.; LOURENÇÃO, A.L. Variation in the host preferences and responses of Ascia monuste orseis Godart (Lepidoptera: Pieridae) to cultivars of collard greens Brassica oleracea (L.) var. acephala. Journal of Pest Science, v.84, p.429-436, 2011. DOI: 10.1007/ s10340-011-0378-x.

SINCLAIR, J.B.; KOGAN, M.; MCGLAMERY, M.D. Guidelines for the integrated management of soybean pests. Urbana: National Soybean Research Laboratory, 1997. 48p.

SMITH, C.M. Plant resistance to arthropods: molecular and conventional approaches. Dordrecht: Springer, 2005. 426p. DOI: 10.1007/1-4020-3702-3.
SMITH, C.M.; CLEMENT, S.L. Molecular bases of plant resistance to arthropods. Annual Review of Entomology, v.57, p.309-328, 2012. DOI: 10.1146/annurev-ento-120710-100642.

SOUZA, B.H.S. de; BOIÇA JÚNIOR, A.L.; JANINI, J.C.; SILVA, A.G. da; RODRIGUES, N.E.L. Feeding of Spodoptera eridania (Lepidoptera: Noctuidae) on soybean genotypes. Revista Colombiana de Entomologia, v.38, p.215-223, 2012.

VON MÉREY, G.E.; VEYRAT, N.; D’ALESSANDRO, M.; TURLINGS, T.C.J. Herbivore-induced maize leaf volatiles affect attraction and feeding behavior of Spodoptera littoralis caterpillars. Frontiers in Plant Science, v.4, article 209, 2013. DOI: 10.3389/ fpls.2013.00209.

WAR, A.R.; PAULRAJ, M.G.; WAR, M.Y.; IGNACIMUTHU, S. Herbivore- and elicitor- induced resistance in groundnut to Asian armyworm, Spodoptera litura (Fab.) (Lepidoptera: Noctuidae). Plant Signaling \& Behavior, v.6, p.1769-1777, 2011. DOI: 10.4161/psb.6.11.17323.

WENDT, J.G.N.; CARVALHO, A.G. de. Desenvolvimento de Urbanus acawoios (Willians, 1926) (Lepidoptera: Hesperiidae) em cultivares de Phaseolus vulgaris L. (Leguminoseae). Revista de Ciências Agroveterinárias, v.5, p.93-101, 2006.

Received on December 3, 2014 and accepted on April 30, 2015 